Agriculture, Agrobusiness and Biotechnology

Vol.60: e17160847, January-December 2017 http://dx.doi.org/10.1590/1678-4324-2017160847 ISSN 1678-4324 Online Edition

\title{
Assessment of Sugarcane Germplasm (Saccharum spp. complex) Against Red Rot Pathogen Colletotrichum Falcatum
}

\author{
Atul Singh ${ }^{\mathbf{1}}$, Pratap Singh ${ }^{\mathbf{1}}$, A K Tiwari ${ }^{1 *}$, B L Sharma ${ }^{\mathbf{1}}$. \\ ${ }^{1}$ Uttar Pradesh Council of Sugarcane Research,Shahjahanpur-242001, UP, India.
}

\begin{abstract}
Red rot, caused by Colletotrichum falcatum Went is the most important disease of sugarcane in India inflicting substantial loss to both cane industry and cane growers. To keep in view the importance of red rot disease of sugarcane, 117 accession of sugarcane germplasm including different Saccharum species and Indian and foreign commercial hybrids were tested against red rot with Cf 07, Cf 08 \& Cf 09 (national pathotypes) by plug method of inoculation. Out of 117, 6 were found resistant and 12 were moderately resistant against red rot and rest were moderately susceptible/susceptible/highly susceptible. Theses resistance and moderately resistant accession can be further utilize to produce resistance varieties against the most devastating pathogen of sugarcane.
\end{abstract}

Key words: Sugarcane, Germplasm, Resistance, Red rot, plug method

*Author for correspondence: ajju1985@gmail.com 
India is a major producer as well as consumer of sugar in the world and produced about 25 metric tons (MT) of sugar from 360 MT of sugarcane in year 2011-13, contributing about $15 \%$ of the total sugar production of the world. A quantum of sugar is produced from sugarcane; however, this crop faces a number of problems such as low cane productivity, biotic and abiotic stresses, high cost of cultivation, unavailability of seed cane of newly released varieties, post-harvest losses and low sugar recovery ${ }^{[1]}$. Among biotic stress, disease caused by fungus are of major importance. Red rot which is caused by Colletrichum facutum is known as cancer of sugarcane, which is the most ravaging fungal disease of sugarcane in sub-tropical belt of India. It has appeared many times in the form of epiphytotic in U.P., Bihar, Haryana, Punjab and Kerala. Since, it reported in 1902 from India, the disease to be a major challenge for sugarcane cultivation in the all sugarcane growing states of India $^{[2,3]}$. Most of the commercial varieties of sugarcane have been wiped out of cultivation only due to this disease. Red rot causes drastic reduction in yield and deterioration in juice quality. Thus, this disease affects both growers and millers. Varietal resistance is a major approach to combat the disease for being cost effective, more reliable and an integral component of Integrated Disease Management. Therefore, breeding for red rot resistance is a need based requirement in Sugarcane Breeding Programme ${ }^{[4,5]}$. Keeping this in view, the present study has been undertaken to (i) identify new sources of resistance to $C$. falcatum, (ii) introduce new source of resistance in conventional breeding programme, (iii) estimate relative frequency of resistance in sugarcane genotypes collected from different agroclimatic regions of the world.

One hundred seventeen accessions of sugarcane belonging to different geographical and ecological conditions of the world including S. officinarum (4), S. barberi (5), S. sinence (8), S. robustum (2), S. spontaneum (11), ISH (8), foreign commercial hybrid (45), Indian hybrids/ varieties/ genotypes (34) were grown and screened against mixture of virulent pathotypes of red rot pathogen, i e Cf 07, Cf 08 and Cf 09 collected from different parts of India, by plug method of inoculation in autumn season at U.P. Council of Sugarcane Research, Shahjahanpur. In plug method, plug hole made by a cork borer on the third exposed internode from bottom ${ }^{[6]}$. The inoculation were made when 6-7 well formed internodes were developed. Two drops of spore suspension- (106 ml-1) were put in the hole by a large syringe. The hole was then plugged and sealed with wax. Fifteen canes of each accession were inoculated in the last week of August and evaluation were done after 60 days of inoculation on the basis of $0-9$ scale $^{[6]}$ and were graded into resistant (R) moderately resistant (MR), moderately susceptible (MS), susceptible (S) and highly susceptible (HS).

It is evident from the results that out of 117 accessions tested, six were resistant, twelve moderately resistant, nine moderately susceptible and rest 90 were susceptible/ highly susceptible to red rot (Table 1). The experimental findings also revealed that out of 5 species of Saccharum, S. spontaneum showed maximum percentage of resistance (81.8) followed by $S$. sinence (37.5) and S. officinarum (25.0). S. robustum and $S$. barberi showed maximum number of susceptible genotypes. Among foreign hybrids of sugarcane, only 11.8 percent were moderately resistant while among Indian hybrids only 9.6 percent were moderately resistant. Only 2.2 percent of the total accessions were found moderately resistant to red rot. Management of the red rot disease of sugarcane is the most challenging work for the researchers. Incidence of the disease depends upon weather conditions, genotypes, presence of virulent pathogen and time for disease appearance. The genetics of inheritance of red rot resistance is not well established ${ }^{[7]}$. Control of this disease is based on the use of disease-free planting material, resistant varieties and fungicide treatments which possesses many shortcomings, e.g. development of resistance 
Red rot assessment in sugarcane germaplasm

varieties against fungicides, emergence of new pathotypes and undesired effects on the environment ${ }^{[8]}$. Considerable efforts has been made to develop varietal resistance against prevailing mycoflora of the red rot pathogen and to maintain the resistant varieties in pipeline by incorporating red rot resistant, in this connection, the present study which revealed that six accessions resistant and twelve found moderately resistant against red rot pathogen through plug method of inoculation can be further utilized during breeding programme to produce new resistant varieties of sugarcane against $C$. falcutum isolates.

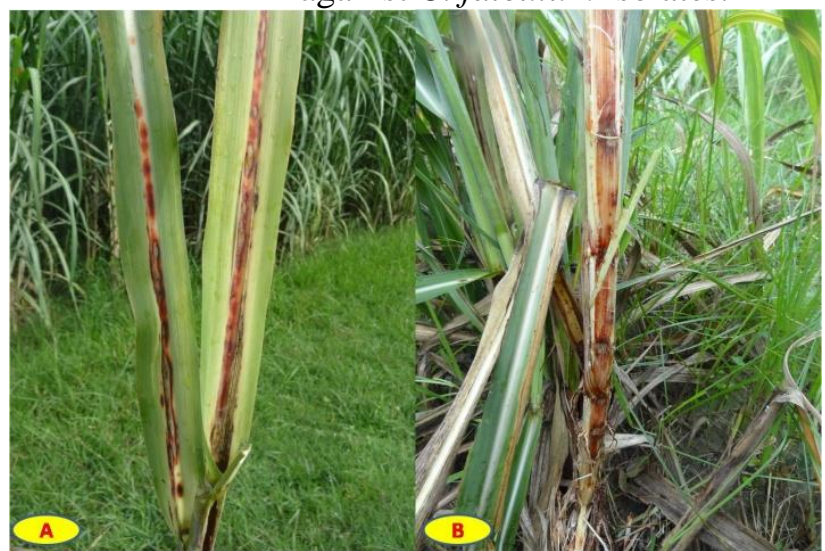

Figure 1 - red to symptoms on leaf of sugarcane A); red rot symptoms on longitudinal cutted cane B)

Table 1 - Performance of sugarcane world accessions against Colletotrichum falcatum

\begin{tabular}{|c|c|c|}
\hline $\begin{array}{l}\text { Category of } \\
\text { resistance }\end{array}$ & Name of the accessions & $\begin{array}{l}\text { Total number } \\
\text { of accessions }\end{array}$ \\
\hline Resistant & 'N 66', 'N 87', 'N 144', 'N 197’, 'SES 594', 'WS 18' & 6 \\
\hline Moderately resistant & $\begin{array}{l}\text { 'Calcutta', 'Cayana', 'CP 33-130', 'CP 44-43', 'BO 28', 'Dr. lal', } \\
\text { 'Kheli', 'Malani', 'Pusa 4', 'POJ 2946', 'Ramsal', 'TUC 521' }\end{array}$ & 12 \\
\hline $\begin{array}{l}\text { Moderately } \\
\text { susceptible }\end{array}$ & $\begin{array}{l}\text { 'Agaul', 'B 28/92', 'Co 7503', 'CoS } 8121 \text { ', 'H 6538', 'Lal khadi', } \\
\text { 'POJ 2878', 'Sugar Doctor', 'Uba white' }\end{array}$ & 9 \\
\hline Susceptible & $\begin{array}{l}\text { 'B 34-104', 'Bajpur 3', 'Co 796', 'Co 8135', 'Co 8204', 'CoS 513', } \\
\text { 'CP 35-105', 'CP 50-11', 'CP 33-320', 'CP 346-347', 'ISH 56', } \\
\text { 'ISH 63', 'ISH 112', 'Kansar', 'NCo 3140', 'POJ 2818', 'Q 46' }\end{array}$ & 17 \\
\hline Highly susceptible & $\begin{array}{l}\text { 'B 29-228', 'B 29-250', 'B 38-22', 'B 46-346', 'B 45-124', 'B 49-228', } \\
\text { 'B 3772', 'Baheri-2', 'Co 213', 'Co 285', 'Co 312', 'Co 331', 'Co } \\
337 \text { ', 'Co 453', 'Co 621', 'Co 701', 'Co 730', 'Co 790', 'Co 822', 'Co } \\
1111 \text { ', 'Co 1149', 'Co 1308', 'Co 1321', 'Co 1336', 'Co 1348', 'Co } \\
\text { 1918', } \\
\text { 'Co 6307', 'Co 6612', 'Co 7407', 'Co 7415', 'Co 7443', 'Co 8208', } \\
\text { 'Co 8008', 'CoH 56', 'CoP 2', 'CoP 48-103', 'CP 36-105', 'CP 44- } \\
120 \text { ', 'CoS 245', 'CoS 510', 'CoS 514', 'CoS 541', 'CoS 770', } \\
\text { 'Dhaula', } \\
\text { 'H 35-263', 'H 5174', 'HM 223', 'HP 89', 'I 672', 'ISH 35', 'ISH 43', } \\
\text { 'ISH } 111 \text { ', 'ISH 163', 'ISH 168', 'Khatuya', 'Khadya', 'Kabanjera', } \\
\text { 'NG 61', 'NG 77-56', 'Pathari', 'Panshahi', 'Pararia', 'Pindra', } \\
\text { 'Vellai', 'POJ 1128', 'POJ 2228', 'POJ 2883', 'PR 1014', 'PR 1048', } \\
\text { 'Q 49', } \\
\text { 'Q 68', 'Q 79', '57 NG 78' }\end{array}$ & 73 \\
\hline
\end{tabular}




\section{ACKNOWLEDGMENT}

Authors wish to thanks Dr M L Sharma (Ex Director, UP Council of Sugarcane Research) and Dr M P Singh (Retired Scientific Officer) for their continuous support and encouragement.

\section{REFERENCES}

1- Tiwari AK, Lal M, Singh AK. Current Status of Sugarcane Research in India. Published by Nova Publisher USA. 2015a; pp 1-170.

2- Tiwari AK, Bharti YP, Tripathi S, Mishra N, Lal M, Rao GP, Sharma PK, Sharma ML. Biotechnological approaches to improve sugarcane crop with special reference to disease resistance. Acta Phytopathol et Entomol Hung. 2010; 45 (2):235-249.

3- Tiwari AK, Kumari K, Singh SP, Mishra N, Singh A, Sharma BL. Fusarium moniliforme associated with Sugarcane leaf binding disease in India and its possible management. In: Current trends in plant disease diagnostic and management practices (Eds. Kumar P, Gupta VK, Tiwari AK, Kamle M) Published by Springer. 2016; pp187-191.

4- Singh Atul, Singh R K, Singh M P and Singh S B. Sources of resistance to red rot (Colletotrichum falcatum) with quality in sugarcane. Indian Journal of Agricultural Sciences .2004; 74(6): 334-6.

5- Singh H B. Red rot of sugarcane: Research progress and challenges in Biological Management. International symposium on Technologies to Sugar productivity in developing countries, Guilin, P.R. China: 2006; 400-401.

6- Srinivasan $\mathrm{KV}$, Bhat $\mathrm{S} \mathrm{R}$. Red rot of sugarcane criteria for grading resistance. Indian Botanical society. 1961; 40, 566-577

7- Viswanathan R, Sundar AR, Malathi P, Padmanaban P. Red Rot of Sugarcane (Ed., T.R. Shanthy). Sugarcane Breeding Institute, Coimbatore. 2011.

8- Mishra MK and Behera B. Pathogenic and molecular variability of Colletotrichum falcatum Went. Isolates from sugarcane with red rot disease symptoms. Journal of Crop Science and Biotechnology. 2009;12 : 31-36 
Red rot assessment in sugarcane germaplasm

\section{Erratum}

In Article "Assessment of Sugarcane Germplasm (Saccharum spp. complex) Against Red Rot Pathogen Colletotrichum Falcatum", with DOI number: http://dx.doi.org/10.1590/1678-43242017160847, published in journal Brazilian Archives of Biology and Technology, vol. 60, the 01 page.

That read:

“http://dx.doi.org/10.190/1678-4324-2017160847"

Read:

“http://dx.doi.org/10.1590/1678-4324-2017160847" 